U. S. DEPARTMENT OF COMMERCE BUREAU OF STANDARDS

\title{
STEEL BONE PLATES AND SCREWS
}

COMMERCIAL STANDARD CS37-31

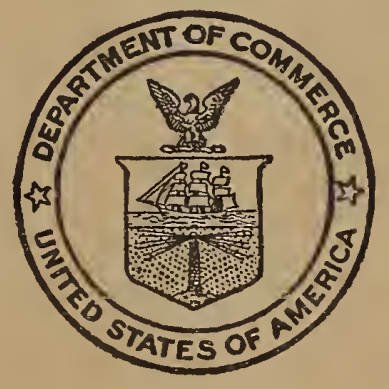

A RECORDED STANDARD OF THE INDUSTRY 
Below are described some of the series of publications of the Department of Commerce which deal with various phases of waste elimination.

Simplified Practice Recommendations.

These present in detail the development of programs to eliminate unnecessary variety in sizes, dimensions, styles, and types of over 120 commodities. They also contain lists of associations and individuals who have indicated their intention to adhere to the recommendations. These simplified schedules, as formulated and approved by the industries, are indorsed by the Department of Commerce.

American Marine Standards.

These are promulgated by the American Marine Standards Committee, which is controlled by the marine industry and administered as a unit of the division of simplified practice. Their object is to promote economy in construction, equipment, maintenance, and operation of ships. In general, they provide for simplification and improvement of design, interchangeability of parts, and minimum requisites of quality for efficient and safe operation.

\section{Commercial Standards.}

These are developed by various industries under a procedure similar to that of simplified practice recommendations. They are, however, primarily concerned with considerations of grade, quality, and such other characteristics as are outside the scope of dimensional simplification.

Lists of the publications in each of the above series can be obtained by applying to the Bureau of Standards, Washington, D. C. 


\title{
U. S. DEPARTMENT OF COMMERCE
}

R.P.LAMONT, Secretary

BUREAU OF STANDARDS

GEORGE K. BURGESS, Director

\section{STEEL BONE PLATES AND SCREWS}

\section{COMMERCIAL STANDARD CS37-31}

\author{
[Issued March 23, 1932]
}

Effective Date for New Production, November 16, 1931

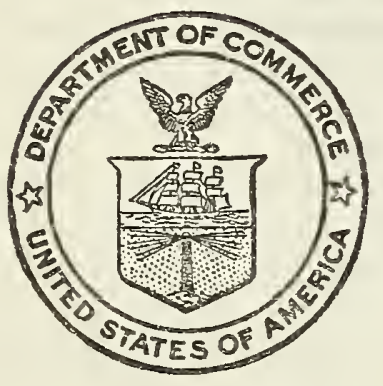

UNITED STATES

GOVERNMENT PRINTING OFFICE

WASHINGTON : 1932 
CONTENTS 


\section{STEEL BONE PLATES AND SCREWS}

\section{ACCEPTORS}

ASSOCIATIONS

American College of Surgeons Chicago, Ill.

American Hospital Association, Chicago, Ill.

American Protestant Hospital Association, Cincinnati, Ohio.

Homeopathic Hospital Association of Delaware, Wilmington, Del.

Hospital Association of Pennsylvania, Sayre, $\mathrm{Pa}$.

Kenosha Hospital Association, Kenosha, Wis.

Montefiore Hospital Association of Western Pennsylvania, The, Pittsburgh, $\mathrm{Pa}$.

National Fracture Committee, American College of Surgeons, Chicago, Ill.

National Tuberculosis Association, New York, N. Y.

National Wholesale Druggists' Association, New York, N. Y.

Santa Fe Coast Lines Hospital Association, Los Angeles, Calif.

Youngstown Hospital Association, The, Youngstown, Ohio.

FIRMS, HOSPITALS, AND SURGEONS

Andrew Memorial Hospital, John A., Tuskegee, Ala.

Arnot-Ogden Memorial Hospital, Elmira, N. Y.

Atlantic City Hospital, Atlantic City, N.J.

Auburn City Hospital, Auburn, N. Y. Auburn Park Hospital (Inc.), Chicago, Ill.

Aultiman Hospital, Canton, Ohio.

Baltimore City Hospitals, Baltimore, Md.

Baptist State Hospital, Little Rock, Ârk.

Barnes Hospital, St. Louis, Mo.

Battle Mountain Sanitarium, Hot Springs, S. Dak.

Beth Moses Hospital, Brooklyn, N. Y.

Betz Co. (Inc.), Frank S., Hammond, Ind.

Birmingham Baptist Hospital, Birmingham, Ala.

Blodgett Memorial Hospital, East Grand Rapids, Mich.
Brigham Hospital, Peter Bent, Boston, Mass.

Broadlawns Hospital, Des Moines, Iowa.

Brockton Hospital Co., Brockton, Mass.

Buhl Hospital, Christian H., Sharon, Pa.

Carnegie Steel Co., Pittsburgh, Pa.

Charleston General Hospital, Charleston, W. Va.

Chester County Hospital, The, West Chester, Pa.

Children's Hospital of Pittsburgh, Pittsburgh, Pa.

Church Home \& Infirmary, The, Baltimore, Md.

City-County Hospital, El Paso, Tex.

City Hospital, Cleveland, Ohio.

City Hospital of Akron, The, Akron, Ohio.

Clark Co., A. M., Chicago, Ill.

Codman \& Shurtleff (Inc.), Boston, Mass.

Cole, A. V., Indiana Harbor, Ind.

Conemaugh Valley Memorial Hospital, Johnstown, Pa.

Cooley Dickinson Hospital, Northampton, Mass.

Corwin Hospital (C. F. \& I. Co.), Pueblo, Colo.

Cotton, Frederic, J., M. D., Boston, Mass.

Delaware Hospital, Wilmington, Del. (in principle).

Delray Industrial Hospital, Detroit, Mich.

Dickson, Frank D., M. D., Kansas City, Mo.

Eastman, Ford, M. D., Erie, Pa.

Eliason, E. L., M. D., Philadelphia, Pa.

Elizabeth General Hospital, Elizabeth, N. J.

Evangelical Deaconess Hospital, Detroit, Mich.

Evangelical Hospital of Chicago, Chicago, Ill.

Fifth Avenue Hospital, The, New York, N. Y.

Flower Hospital, The, Toledo, Ohio.

Fort Sanders Hospital, Knoxville, Tenn.

Frick Coke Co., H. C., Pittsburgh, Pa.

Gale Hospital, Haverhill, Mass.

Garfield Park Hospital, Chicago, I11.

Gillette State Hospital, St. Paul, Minn. 
Glenville Hospital, Cleveland, Ohio.

Grace Hospital, New Haven, Conn.

Hackensack Hospital, Hackensack, N. J.

Hackley Hospital, Muskegon, Mich.

Hahnemann Hospital, Philadelphia, $\mathrm{Pa}$.

Hahnemann Hospital, Scranton, Pa.

Harrisburg Polyclinic Hospital, Harrisburg, Pa.

Hatfield Lawson Hospital, Logan, W. Va.

Highland Park General Hospital, Highland Park, Mich.

Hinsdale Sanitarium \& Hospital, Hinsdale, III.

Homeopathic Hospital of Rhode Island, Providence, R. I.

Hospital for Joint Diseases, New York, N. Y.

Hospital for Ruptured \& Crippled, New York, N. Y.

Hurley Hospital, Flint, Mich.

Indiana University School of Medicine \& Hospitals, Indianapolis, Ind.

Jamison Semple Co., New York, N. Y. Jetter \& Scheerer Products (Inc.), New York, N. Y.

Jewish Hospital, The, Cincinnati, Ohio.

Kingston Hospital, Kingston, N. Y.

LaFayette Home Hospital, LaFayette, Ind.

Latter Day Saints Hospital, Salt Lake City, Utah.

Lawrence \& Memorial Associated Hospitals (Inc.), New London, Conn.

Lentz \& Sons, Charles, Philadelphia, $\mathrm{Pa}$.

Livezey Surgical Supply, Newark, N. J.

Lutheran Hospital, St. Louis, Mo.

Lutheran Hospital \& Gundersen Clinic, La Crosse, Wis.

Lutheran Hospital Society of Southern California (Inc.), Los Angeles, Calif.

Manger Co., C. C., Compton, Calif.

Massachusetts General Hospital, Boston, Mass.

Memorial Hospital, The, Worcester, Mass.

Mercy Hospital, Altoona, Pa.

Methodist Hospital, The, Sioux City, Iowa.

Metropolitan Hospital, Welfare Island, New York, N. Y.

Miami Valley Hospital, The, Dayton, Ohio.

Milwaukee County Hospital, Wauwatosa, Wis.

Milwaukee Hospital, Milwaukee, Wis.

Minneapolis General Hospital, Minneapolis, Minn.

Misericordia Hospital, Milwaukee, Wis.

Monmouth Memorial Hospital, Long Branch, N.J.

Montgomery Hospital, Norristown, $\mathrm{Pa}$.

Morningside Hospital, Tulsa, Okla.

Mount Sinai Hospital, New York, N. Y.
Mount Sinai Hospital of Chicago, Chicago, Ill.

Mount Sinai Hospital of Cleveland, Cleveland, Ohio.

Mount Zion Hospital, San Francisco, Calif.

Mueller \& Co., V., Chicago, Ill.

Muhlenberg Hospital, Plainfield, N. J.

Murphy Hospital, John B., Chicago, III.

Murray, Clay Ray, M. D. New York, N. Y.

New Rochelle Hospital, New Rochelle, N. Y.

New York Orthopaedic Dispensary and Hospital, New York, N. Y.

North Country Community Hospital, Glen Cove, N. Y.

Ohio Valley General Hospital, Wheeling, W. Va.

Oklahoma City Clinic, Wesley Hospital, Oklahoma City, Okla.

Oneida County Hospital, Rome, N. Y. Orange County Hospital, Orange, Calif.

Packer Hospital, Robert, Sayre, Pa.

Pennsylvania Hospital, Philadelphia, Pa.

Physician's Supply Co. of Philadelphia, Philadelphia, Pa.

Pierce Co., Harvey R., Philadelphia, $\mathrm{Pa}$.

Pilling \& Son Co., The George P., Philadelphia, Pa.

Pittsburgh City Home and Hospitals, Mayview, $\mathrm{Pa}$.

Receiving Hospital, Detroit, Mich.

Red River Lumber Co. (Westwood Hospital), Westwood, Calif.

Riverside County Hospital, Arlington, Calif.

Rochester General Hospital, Rochester, N. Y.

Rochester General Hospital, Rochester, $\mathrm{Pa}$.

Roper Hospital, Charleston, S. C.

Saginaw General Hospital, Saginaw, W. S., Mich.

St. Alexis Hospital, Cleveland, Ohio.

St. Charles Hospital, Port Jefferson, L. I., N. Y.

St. Francis Hospital, San Francisco, Calif.

St. John's Hospital, Fargo, N. Dak.

St. Joseph's Hospital, Reading, Pa.

St. Joseph's Hospital, St. Joseph, Mo.

St. Josephi Hospital, Phoenix, Ariz.

St. Luke's Home and Hospital, Utica, N. Y

St. Luke's Hospital, Bethlehem, Pa.

St. Luke's Hospital, Boise, Idaho.

St. Luke's Hospital, Denver, Colo.

St. Luke's Hospital, Fargo, N. Dak.

St. Luke's Hospital, Jacksonville, Fla.

St. Luke's Hospital of Newburgh, N. Y., Newburgh, N. Y.

St. Luke's Hospital, Racine, Wis. 
St. Luke's Hospital of New Bedford, New Bedford, Mass.

St. Mary's Hospital, San Francisco, Calif.

St. Mary's Hospital for Children (Inc.), New York, N. Y.

St. Paul's Hospital, Dallas, Tex.

San Joaquin General Hospital, French Camp, Calif.

San Jose Hospital (Inc.), San Jose, Calif.

Santa Clara County Hospital, San Jose, Calif.

Santa Fe R. R. Co. (Santa Fe Hospital), Topeka, Kans.

Seattle General Hospital, Seattle, Wash.

Southern Pacific Hospital, Houston, Tex.

South Highlands Infirmary, Birmingham, Ala.

Spartanburg General Hospital, Spartanburg, S. C.

Springfield Hospital, The, Springfield, Mass.

State Hospital, Columbia, S. C.

Strong Memorial Hospital, Rochester, N. $Y$.

Stuart Circle Hospital, Richmond, Va.

Sutter Hospital, Sacramento, Calif.

Swedish Hospital, Minneapolis, Minn.

Tampa Municipal Hospital, Tampa, Fla.

Tennessee Coal, Iron \& Railroad Co., Fairfield, Ala.

Truesdale Hospital, The, Fall River, Mass.

Tucker, W. J., M. D., Ashland, Wis.

Union Hospital, Terre Haute, Ind.

Union Hospital in Fall River, Mass., Fall River, Mass.

University and Crippled Children's Hospitals, Oklahoma City, Okla.

University Hospitals of Cleveland, The, Cleveland, Ohio.

University of California Hospital, San Francisco, Calif.

University of Chicago Clinies, Chicago, III.

University of Chicago, Rush Miedical College, Chicago, Ill.

University of Colorado School of Medicine and Hospitals, Denver, Colo.
University of Illinois College of Medicine, Chicago, Ill.

University of Oklahoma School of Medicine, Oklahoma City, Okla.

Vassar Bros. Hospital, Poughkeepsie, N. Y.

Waterbury Hospital, Waterbury, Conn.

Welborn Hospital Clinic, Evansville, Ind.

Wesley Memorial Hospital, Chicago, IIl.

Western Pennsylvania Hospital, The, Pittsburgh, Pa.

Westmoreland Hospital, Greensburg, Pa.

West Side Hospital and Dispensary, New York, N. Y.

Wilkes Barre General Hospital, WilkesBarre, $\mathrm{Pa}$.

Wilson, Philip D., M. D., Boston, Mass. Wilson Memorial Hospital, Charles. S. Johnson City, N. Y.

Wisconsin State Medical Society, Madison, Wis.

Woodland Clinic, Woodland, Calif.

Woonsocket Hospital, Woonsocket, R. I.

Worcester City Hospital, Worcester, Mass.

\section{GOVERNMENT}

Freedmen's Hospital, Washington, D. C.

U. S. Naval Hospital, Chelsea, Mass.

U. S. Naval Hospital, Great Lakes, III.

U. S. Naval Hospital, Washington, D. C.

U. S. Naval Medical Supply Depot, Brooklyn, N. Y.

U. S. Soldiers' Home Hospital, Washington, D. C.

U. S. Veterans' Hospital, Washington, D. C.

Walter Reed General Hospital, Washington, D. C.

U. S. S. Relief (Navy hospital ship), San Pedro, Calif.

United States Public Health Service, Leavenworth, Kans.

'Treasury Department, Washington, D. C.

Veterans' Administration, Washington, D. C.

War Department, Washington, D.C. 



\section{STEEL BONE PLATES AND SCREWS}

\section{COMMERCIAL STANDARD CS37-31}

On June 18, 1931, a general conference of representative manufacturers, distributors, and users of steel bone plates and screws adopted a commercial standard for this commodity. The industry here has since accepted and approved for promulgation by the Department of Commerce, through the Bureau of Standards, the commercial standard shown herein.

The standard became effective for new production on November $16,1931$.

Promulgation recommended.

Promulgated.

Chief, Division of Trade Standards.

Approved.

George K. Burgess, Director, Bureau of Standards.

R. P. Llamont, Secretary of Commerce. 


\section{SCOPE}

1. This commercial standard covers the physical and metallur-. gical requirements, design, dimensions, workmanship, and finish of steel bone plates and screws available for use in the reduction of bone fractures, together with the packaging, identification, and certification of quality to buyers.

\section{TYPE AND GRADE}

2. Steel bone plates and screws shall be of the form known as the Sherman type. They shall be made in one grade only.

\section{GENERAL REQUIREMENTS}

3. Workmanship and finish.-Steel bone plates and screws shall be of good workmanship without apparent flaws or defects. They shall be thoroughly cleaned and polished smooth after tempering and then given a blued steel finish.

4. Metallurgical requirements. ${ }^{1-(a)}$ The steel for both plates and screws shall be chromium-vanadium steel conforming to the following requirements as to chemical composition:

Carbon__._.

Manganese

Chromium

Phosphorous.

Sulphur _...

Vanadium _....

(b) The plates and screws, after forming, shall be heat treated to a hardness of not less than 43 or more than 53 , as determined by the Rockwell hardness tester using the $\mathrm{C}$ scale and the $150 \mathrm{~kg}$ load on the diamond cone penetrator.

\section{DETAIL REQUIREMENTS}

(a) BONE PLATES

5. Design.-Bone plates shall conform to the Sherman design as shown in Figures 1 and 2, and shall be of good workmanship, provided with accurately drilled and countersunk screw holes. Screw holes in curved plates shall be countersunk after plate is curved.

6. Sizes and dimensions.-Bone plates shall be made in 14 sizes with dimensions and contour to conform with Table 1 and Figures 1 and 2.

7. Tolerances.-Tolerances are as given in Table 1.

1 These requirements are the same as for Society of Automotive Engineers steel 6150, according to 1931 S. A. E. handbook. 
TABLE 1.-Plates, sizes and dimensions.

\begin{tabular}{|c|c|c|c|c|c|c|c|c|}
\hline \multirow[b]{2}{*}{ - } & \multirow[b]{2}{*}{ No. } & \multirow{2}{*}{$\begin{array}{l}\text { Total } \\
\text { length } \\
\pm 1 / 16\end{array}$} & \multirow{2}{*}{$\begin{array}{c}\text { Thick- } \\
\text { ness } \\
(T) 1 \\
\pm \mathrm{P} .015\end{array}$} & \multirow{2}{*}{$\begin{array}{l}\text { Num- } \\
\text { ber of } \\
\text { holes }\end{array}$} & \multicolumn{2}{|c|}{ Width } & \multirow{2}{*}{$\begin{array}{l}\text { Bevel } \\
(B)^{1}\end{array}$} & \multirow{2}{*}{$\begin{array}{l}\text { Radius of } \\
\text { curva- } \\
\text { ture } \\
(R) \perp\end{array}$} \\
\hline & & & & & $\begin{array}{l}W 1 \\
\pm P .015\end{array}$ & $\begin{aligned} & Y^{1} \\
& 015\end{aligned}$ & & \\
\hline & & $\begin{array}{c}\text { Inches } \\
5-7 / 16 \\
5-7 / 16 \\
419 / 32 \\
419 / 32 \\
419 / 32\end{array}$ & $\begin{array}{l}\text { Tnch } \\
0.095 \\
.095 \\
.095 \\
.083 \\
.083\end{array}$ & $\begin{array}{l}8 \\
6 \\
6 \\
6 \\
6\end{array}$ & $\begin{array}{c}\text { Inch } \\
0.406 \\
.406 \\
.406 \\
.406 \\
.406\end{array}$ & $\begin{array}{c}\text { Inch } \\
0.260 \\
.260 \\
.215 \\
.215 \\
.228\end{array}$ & $\begin{array}{c}\text { Inch } \\
3 / 64 \\
3 / 64 \\
3 / 64 \\
.041 \\
.041\end{array}$ & $\begin{array}{l}3 \\
3 \\
3 \\
3 \\
3 \\
3\end{array}$ \\
\hline & & $\begin{array}{r}321 / 32 \\
31 / 16 \\
31 / 16 \\
2.930 \\
2.227\end{array}$ & $\begin{array}{l}.065 \\
.083 \\
.055 \\
.065 \\
.065\end{array}$ & $\begin{array}{l}6 \\
4 \\
4 \\
4 \\
4\end{array}$ & $\begin{array}{l}.375 \\
.375 \\
.375 \\
.336 \\
.336\end{array}$ & $\begin{array}{l}.146 \\
.156 \\
.156 \\
.165 \\
.125\end{array}$ & $\begin{array}{l}.025 \\
.041 \\
.025 \\
.025 \\
.025\end{array}$ & $\begin{array}{r}3 / 8 \\
3 / 8 \\
3 / 8 \\
\text { Flat. } \\
\text { Flat. }\end{array}$ \\
\hline & & $\begin{array}{l}1.960 \\
1.715 \\
1.440 \\
1.170\end{array}$ & $\begin{array}{l}.065 \\
.065 \\
.065 \\
.065\end{array}$ & $\begin{array}{l}4 \\
3 \\
3 \\
2\end{array}$ & $\begin{array}{l}.336 \\
.325 \\
.360 \\
.360\end{array}$ & $\begin{array}{l}.125 \\
.112 \\
.186 \\
.186\end{array}$ & $\begin{array}{l}.025 \\
.025 \\
.025 \\
.025\end{array}$ & $\begin{array}{l}\text { Flat. } \\
\text { Flat. } \\
\text { Flat. } \\
\text { Flat. }\end{array}$ \\
\hline
\end{tabular}

1 See Figures 1 and 2, pp. 4 and 5.

8. Inspection and tests.- Each plate shall be tested for hardness before sale or offering for sale as conforming to this specification. Hardness impressions shall be made as near the ends of the plate as practicable, and not in the mid section of any plate which is to be put into service.

9. Stamping.-Each bone plate shall be stamped near an end with the name or trade-mark of the manufacturer and with the designation CS37-31, indicating conformity to this specification. No stamping shall be allowed on the mid section. Stamping shall not be so deep as to appreciably weaken the plate, and shall be done before hardening.

10. Packaging. - Each individual plate shall be sealed in a transparent envelope so that the seal or envelope must be broken to remove the plate. The envelope shall bear a mark showing the size number of the plate contained therein.

11. Guarantee label.-Each envelope containing a plate shall bear a label worded as follows: "The ............ Co. certifies this steel bone plate to conform to all requirements of Commercial Standard CS37-31 issued by the U. S. Department of Commerce."

(b) SCREWS FOR ATTACHING STEEL BONE PLATES

12. Material.-The steel for screws shall be as specified in paragraph $4(a)$, and shall be heat treated as specified in paragraph $4(b)$.

13. Design.-Screws for attaching steel bone plates shall be of the Sherman self-tapping design, provided with accurately cut selftapping flutes and center hole for use with special self-centering screw driver.

14. Sizes and dimensions.-Screws shall be made in 11 sizes with dimensions as shown in Table 2 and Figure 3.

TABLE 2.-Screws, sizes and dimensions

\begin{tabular}{|c|c|c|c|c|c|}
\hline Size & $\begin{array}{l}\text { Dimen- } \\
\text { sion } \\
X\end{array}$ & $\begin{array}{c}\text { Dimen- } \\
\text { sion } \\
Z\end{array}$ & Size & $\begin{array}{l}\text { Dimen- } \\
\text { sion } \\
X\end{array}$ & $\begin{array}{c}\text { Dimen- } \\
\text { sion } \\
Z\end{array}$ \\
\hline $\begin{array}{l}\mathrm{A} \\
\mathrm{B} \\
\mathrm{B} \\
\mathrm{C} \\
\mathrm{D} \\
\mathrm{E}\end{array}$ & $\begin{array}{r}\text { Inches } \\
3 / 8 \\
1 / 2 \\
5 / 8 \\
3 / 4 \\
7 / 8 \\
1\end{array}$ & $\begin{array}{r}\text { Inch } \\
3 / 16 \\
3 / 32 \\
1 / 32 \\
3 / 8 \\
3 / 8 \\
3 / 8\end{array}$ & $\begin{array}{l}\mathrm{G} \\
\mathrm{H} \\
\mathrm{I} \\
\mathrm{J} \\
\mathrm{K}\end{array}$ & $\begin{array}{r}\text { Inches } \\
11 / 8 \\
11 / 4 \\
13 / 8 \\
11 / 2 \\
15 / 8\end{array}$ & $\begin{array}{l}\text { Inch } \\
3 / 8 \\
3 / 8 \\
3 / 8 \\
3 / 8 \\
3 / 8\end{array}$ \\
\hline
\end{tabular}

$98994^{\circ}-32-2$ 


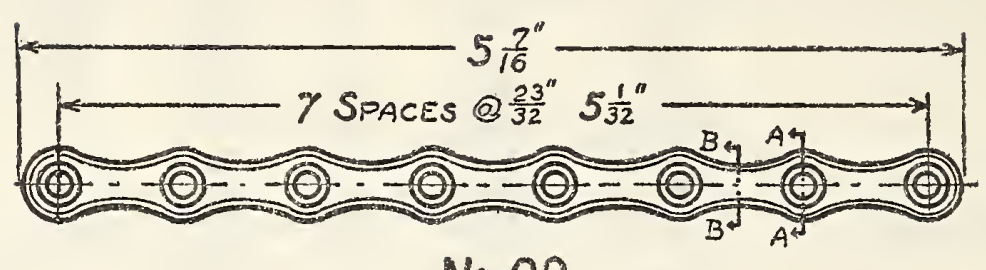

No. 00
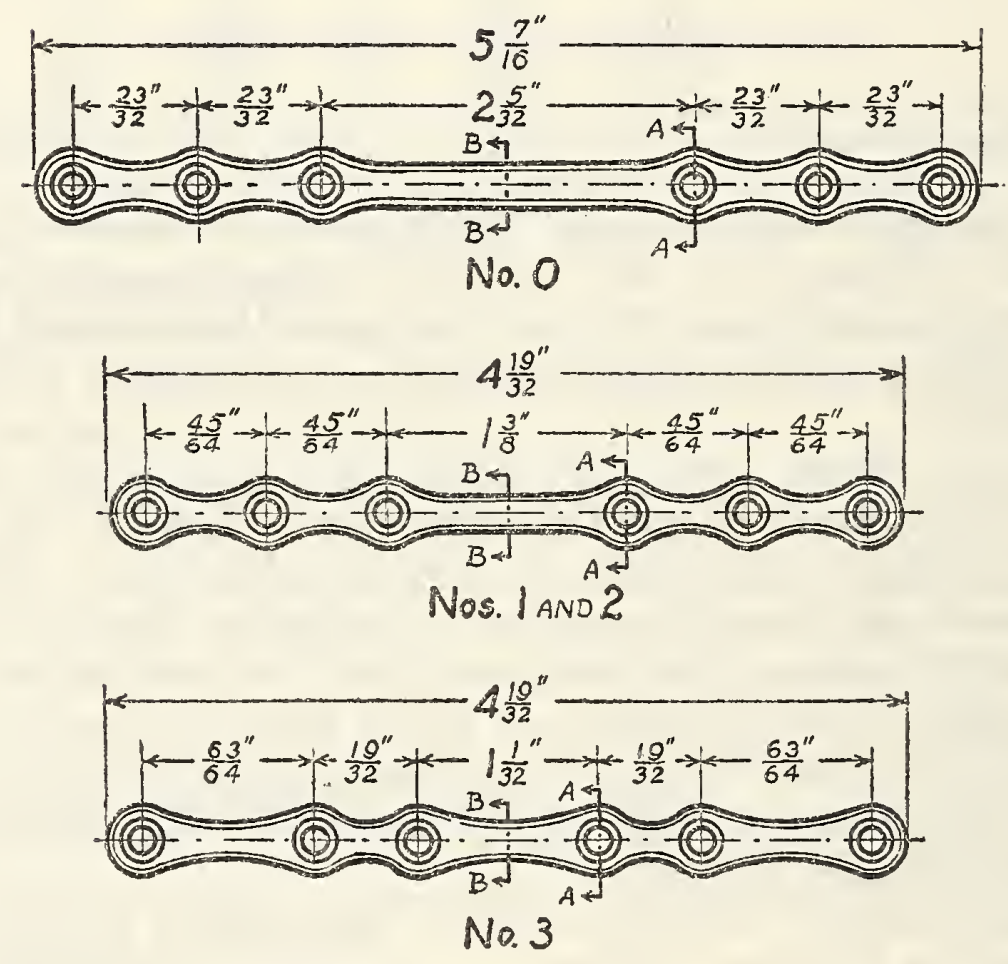

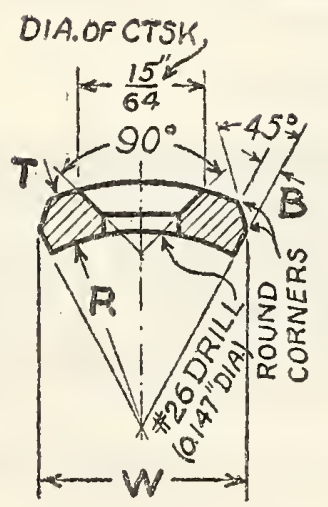

SECTIONAA (ENLARGED)
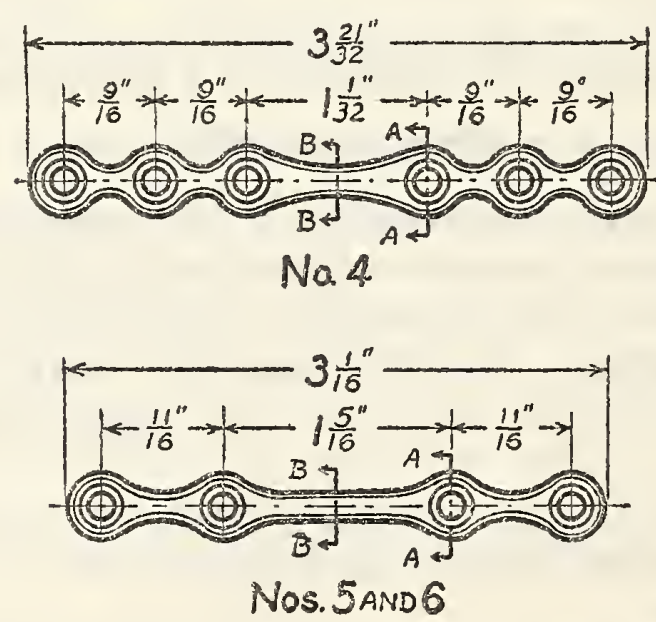

Figure 1.-Curved bone plates (See Table 1 for dimensions not given)

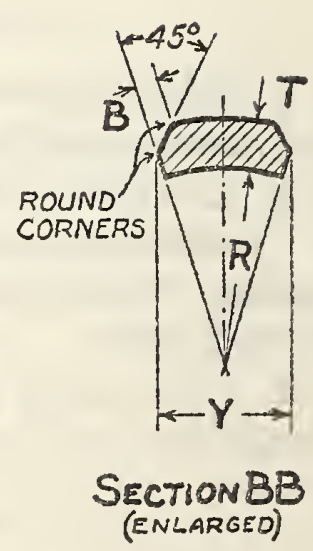




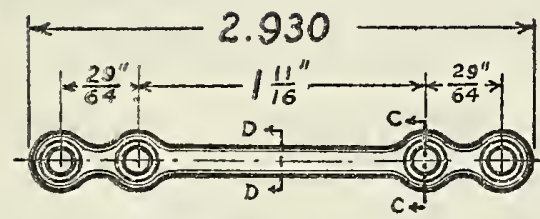

No. $6 \frac{1}{2}$

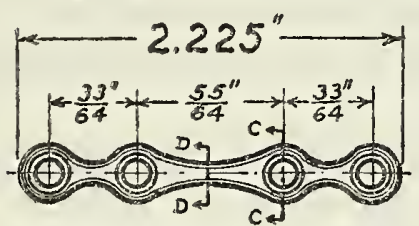

No. 7

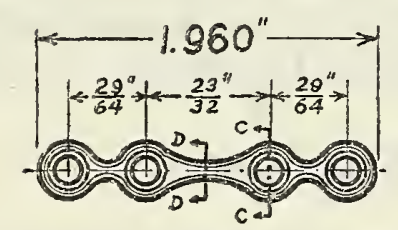

No. 8

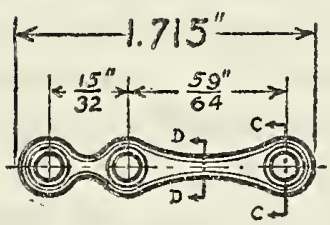

No.10

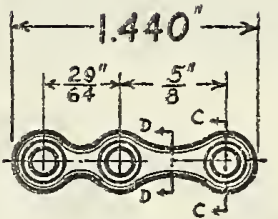

No.l1

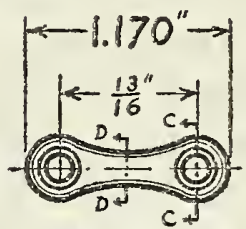

No.12

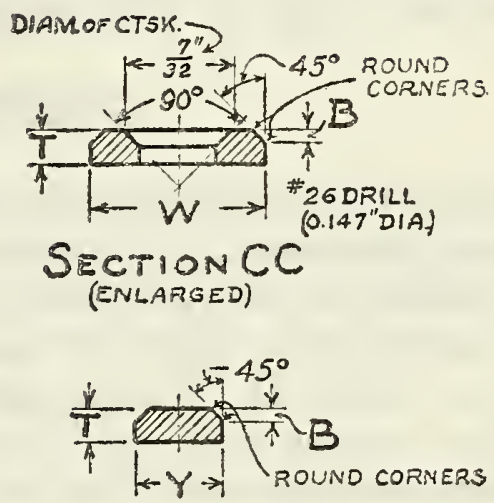

SECTIONDD (ENLARGED)

Figure 2.-Flat bone plates

(See Table 1 for dimensions not given)

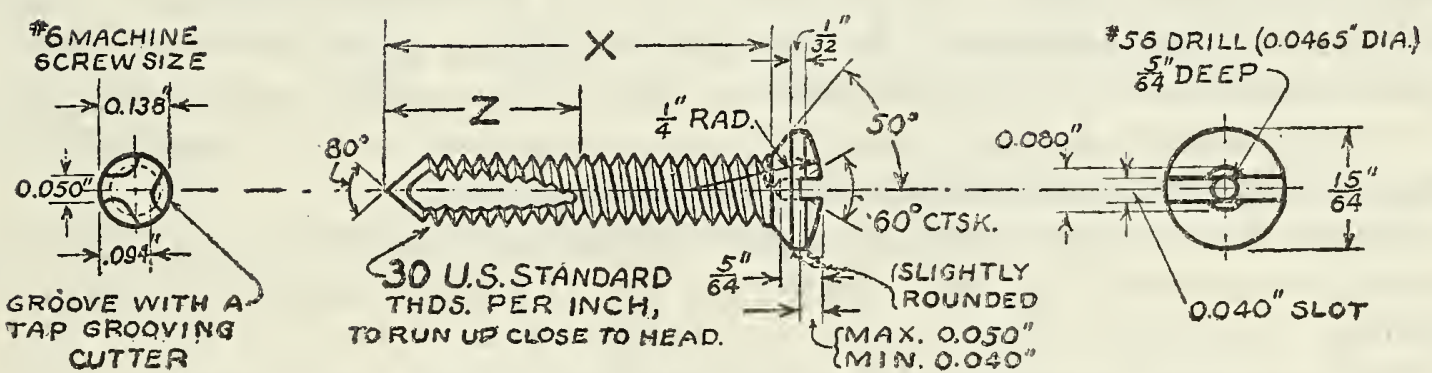

FIGURE 3.-Self-tapping screw

(See Table 2 for dimensions $X$ and $Z$ ) 
15. Packaging.- Screws shall be packaged in lots of 3 or 6 of one size, in transparent envelopes so sealed that the seal or envelope must be broken to remove screws. Each envelope containing screws shall bear a label stating the size and number of screws contained therein.

16. Guarantee label.-Each envelope containing screws shall bear a guarantee label worded as follows: "The _......... Co. certifies these screws to conform to all requirements of Commercial Standard CS37-31 issued by the U. S. Department of Commerce."

\section{HISTORY OF PROJECT}

In December, 1930, the American College of Surgeons, through Dr. Philip D. Wilson, chairman of the subcommittee on steel bone plates and screws of its National Fracture Committee, requested the assistance of the Bureau of Standards in the establishment of a commercial standard for this commodity.

Two preliminary conferences of members of the subcommittee with representatives of the Bureau of Standards were held in Washington, D. C., and a tentative draft of specifications prepared. This draft was approved by the subcommittee on steel bone plates, and screws, and at its request a general conference of producers, distributors, and users was held in Philadelphia, Pa., June 18, 1931.

\section{GENERAL CONFERENCE}

Invitations to attend this conference were mailed to all known individuals and organizations interested in steel bone plates. F. W. Reynolds, of the Bureau of Standards, presided and reviewed briefly the usual procedure for the establishment of a commercial standard.

Dr. Philip D. Wilson presented the proposed commercial standard to the conference, and explained the reasons for the desirability of closer control over the quality and dimensions of steel bone plates and screws. He reviewed the history of the project from the beginning of the investigation of conditions by the American College of Surgeons in 1929 leading to the request for the establishment of a commercial standard and the calling of this conference.

The purpose of the establishment of a commercial standard for this commodity was shown to be twofold; (1) to record definite quality and dimensional standards for steel bone plates and screws representing the concensus of manufacturers and the surgical profession as to the requirements desired, and (2) to guarantee to the hospitals and surgeons products meeting these requirements.

Letters from organizations and individuals unable to attend the meeting were read by the chairman for the information of the conference.

The proposed commercial standard was then reviewed in detail and a few minor changes in the wording of the specification recommended.

The conference then voted unanimously to adopt the specification as corrected and recommended its circulation to those interested for acceptance. 


\section{STANDING COMIMITTEE}

The general conference voted to request the subcommittee on steel bone plates and screws of the National Fracture Committee to appoint a standing committee, including Dr. P. D. Wilson as chairman and a representative of the Bureau of Standards as secretary, this committee to include representatives of the hospitals, surgeons, manufactures, and distributors.

The committee, was appointed as follows:

Dr. P. D. Wilson, chairman, American College of Surgeons.

Dr. J. F. BARRY, Veterans' Administration.

O. F. Cochrane, Kny-Scheerer Corporation.

Capt. E. J. Grow, Navy Department.

Maj. N. T. KIRK, Walter Reed Hospital.

Harvey R. Pierce, Harvey R. Pierce Co.

Charles J. Pilling, Geo. P. Pilling \& Sons Co.

John M. Smith, American Hospital Association.

F. W. Reynolns, secretary, Bureau of Standards.

\section{REVISION INTERVAL}

The normal interval at which proposed revisions will be considered by the standing committee was set at one year.

\section{EFFECTIVE DATE}

It was voted that the commercial standard be made effective 30 days after announcement of formal acceptance of the standard. Accordingly, November 16, 1931, has been announced as the effective date.

\section{CERTIFICATION PLAN}

The conference voted its approval of the certification plan and requested its application to steel bone plates and screws manufactured in conformance to the commercial standard.

The certification plan as applied by the Bureau of Standards to commercial standards consists in the compilation and distribution of lists of manufacturers who are willing, when requested to do so, to certify to purchasers that products supplied by them comply with all the requirements and tests set forth in nationally recognized commercial standards. The plan is also applied to selected Federal specifications.

These lists are available on request to individual consumers, consumer groups, companies, and, in fact, to any prospective purchasers, for their guidance.

The benefits now derived from the use of specifications by large consumers are thus made immediately available to the small consumer, with incidental advantage to the larger consumers of convenience in ordering and accepting material with fewer laboratory tests. The manufacturer also benefits from the well-known economies accompanying "mass production."

The lists of manufacturers "willing-to-certify" to the quality of certain commodities are made by corresponding with, as nearly as possible, all the manufacturers of that product and listing only those who signify their willingness to certify to the purchaser, when re- 
quested to do so, that the commodities delivered actually comply with the commercial standard.

Obviously, the purchaser making use of the lists of "willing-tocertify" manufacturers, will select therefrom such manufacturers as are known (or assumed) by him to be reliable.

The trend toward the purchase of materials of certified quality from sources shown on such willing-to-certify lists supplies added incentive to standardization on the part of other producers, and thus the benefits of the certification plan will be felt by purchasers either directly or indirectly, whether or not they make use of the plan themselves.

\section{COMMERCIAL STANDARDS SERVICE}

Industry has long sensed the need for a wider application and use of specifications developed and approved by nationally recognized organizations. To assist these bodies and the producers and consumers in securing this result and as a natural outgrowth of the movement toward elimination of waste through simplified practice, the Bureau of Standards has set up a procedure under which specifications, properly indorsed, may be printed as official publications of the Department of Commerce and promulgated as "commercial standards." This service parallels that of simplified practice in many respects and is available only upon request.

Broadly speaking, the aim is to continue the same character of cooperative service in this field that is being rendered in simplification. The division of trade standards is not designed to act as a standardizing body, nor will it engage in the preparation of specifications. Its service is mainly promotional in character, since its chief mission is to invite attention to a standard or a specification which any branch of industry may want to promulgate on a nation-wide basis; to determine its eligibility for promulgation; to publish and broadcast it in the event the prerequisites of procedure have been met, including a satisfactory majority acceptance; to facilitate the application of the certification plan for the assurance and convenience of the purchaser; to provide means for periodic audits of adherence; and to cooperate with the Bureau of Foreign and Domestic Commerce in determining the desire of industry relative to translation and promulgation of such specifications as a basis for foreign commerce.

In general, it may be said that a simplification covers types, sizes, and varieties of a commodity which are retained by industry on the basis of demand, whereas a commercial standard establishes definite requirements as to grade, quality, or dimensional tolerances in addition to any limitation of variety desired and accepted by the industry.

\section{ORGANIZATION AND DUTIES OF STANDING COMMITTEE}

In order to carry on the aims and desires of the industry in the standardization of their product, a standing committee is appointed at the general conference. This committee consists of members from each division of the industry, namely, producers, distributors, and consumers, and thus reflects the well-balanced viewpoint of all concerned.

The members of the committee receive all suggestions regarding the commercial standard and consider its revision in the event that such action is desirable and mutually beneficial. 
If the commercial standard does not warrant revision, it is reaffirmed in its existing form, but if any important changes are found desirable, their adoption is recommended by the committee, whereupon the industry is again solicited for written acceptance of the standard in its revised form.

The committee is in effect a centralizing agency for criticisms and comments regarding the commercial standard and is charged with the responsibility of recommending revisions to keep the standard abreast with current industrial practice.

The proper functioning of the committee requires that, when necessary, its members be willing to attend meetings held at some central place, although in many cases it will be possible to conduct the work by correspondence.

When any deceptions in reference to the commercial standard are reported to the standing committee, it applies moral suasion or such other corrective measures as seem desirable. The Department of Commerce has no "police power" to compel adherence; therefore, it is incumbent upon the standing committee to do all in its power to encourage all divisions of the industry to follow the provisions of the commercial standard and contribute in every way possible to its general adoption and usefulness.

\section{YOUR COOPERATION}

As a producer, distributor, or consumer of some of the commodities for which commercial standards have already been established, you are in a position to avail yourself of the benefits arising from the use of quality standards and incidentally to add impetus to this method of eliminating waste.

The first step is a declaration in favor of the standard by recording your intention to adhere, as closely as circumstances will allow, to the standards for those products which you may buy or sell.

The receipt of your signed acceptance will permit the listing of your company in new editions of the commercial standards that you accept.

You will, of course, want to examine any commercial standards before signing a formal acceptance. The Bureau of Standards will, therefore, furnish a copy of any standard under consideration for acceptance. A list of current commercial standards is given on the rear cover.

The publications may also be secured singly or in quantities at a nominal price from the Superintendent of Documents, Washington, D. C. Prices will be furnished upon request.

The acceptance of a commercial standard is an entirely voluntary action and applies to the production, sale, and use of stock items. It is not meant to interfere with the introduction, manufacture, or sale of special sizes and types sometimes required.

Trade associations and individual companies often distribute large numbers of the printed standards for the information and guidance of their members or customers. In such cases it is possible to extend the scope and degree of adherence by urging each recipient to send in an acceptance, bearing in mind that the practical value of any standardization is measured by the observance it receives.

An acceptance form for the commercial standard herein covered is included on page 11. 

ACCEPTANCE OF COMMERCIAL STANDARD

Please sign and return this sheet to Division of Trade Standards, Bureau of Standards, Washington, D. C.

\section{Division of Trade Standards,}

Date

Bureau of Standards,

$$
\text { Washington, D.C. }
$$

Gentlumen: We, the undersigned, do hereby accept the original draft of the commercial standard as our standard practice in the $\left\{\begin{array}{l}\text { production }^{1} \\ \text { distribution } \\ \text { use }^{1}\end{array}\right\}$ of steel bone plates and screws beginning . . . . . . . . . . _ , and will use our best effort in securing its general adoption.

To permit intelligent review of the effectiveness of the commercial standard every year by an accredited committee of all interests, working in cooperation with the Department of Commerce, we plan to supply all data, upon request, which may be necessary for the development of constructive revisions. It is understood that any suggested modifications will be submitted as soon as formulated, and shall not be promulgated until accepted in form similar to this recommendation.

Signature

(A bove signature should be in ink)

(Kindly typewrite or print the following lines)

Title

Company

Street address

City and State.

We are members of the following associations or other organizations interested in the production, sale, or use of steel bone plates and screws:

1 Please designate which group you represent by drawing lines through the other two. In the case of related interests, trade papers, colleges, etc., desiring to record their general approval, the words "In principle" should be added after the signature. 


\section{TO THE ACCEPTOR}

In signing the acceptance blank, please bear the following points clearly in mind:

1. Adherence.-The Department of Commerce has no regulatory powers to enforce adherence to the commercial, standards. Instead, this waste-elimination program is based on voluntary cooperation and self-government in industry. To make this specific standardization operate as a satisfactory example of self-government, it is highly desirable that it be kept distinct from any plan or method of governmental regulation or control. It will be successful according to the degree to which manufacturers, distributors, and purchasers adhere to its terms and conditions.

2. The industry's responsibility.-The department cooperates only on the request of the industry, and assumes no responsibility for industrial acceptance or adherence. This program was developed by the industry on its own initiative. Its success depends wholly on the active cooperation of those concerned.

3. The acceptor's responsibility. - You are entering into an entirely voluntary arrangement, whereby the members of the industry-the distributors and consumers of the product, and other's concernedhope to secure the benefits inherent in commercial standardization. Those responsible for this standard realize that instances may occur in which it will be necessary to supply or purchase items not included therein. The purpose is, however, to secure wider support for nationally recognized standards covering grade, quality, and other characteristics of products. Consumers can make the program a success if, in their purchasing, they will make a definite and conscientious effort to specify in terms of this commercial standard.

4. The department's responsibility.-The function performed by the Department of Commerce is fourfold: First, to act as a coordinator to insure adequate consideration of the needs of all interests; second, to supply such assistance and advice in the development of this program. as past experience with similar programs may suggest; third, to solicit and record the extent of adoption and adherence to the standard; and fourth, to add all possible prestige to this standardization movement by publication and promulgation if and when it is adopted and accepted by all elements directly concerned. 




\section{COMMERCIAL STANDARDS}

CS No.

ITEM

$0-30$. The commercial standards service and its value to business.

1-28. Clinical thermometers.

2-30. Mopsticks.

3-28. Stoddard solvent.

4-29. Staple porcelain (all-clay) plumbing fixtures.

5-29. Steel pipe nipples.

6-31. Wrought-iron pipe nipples (first revision)

7-29. Standard weight malleable iron or steel screwed unions.

8-30. Plain and thread plug and ring gage blanks

9-29. Builders' template hardware.

10-29. Brass pipe nipples.

11-29. Regain of mercerized cotton yarns.

12-29. Domestic and industrial fuel oils.

13-30. Dress patterns.

11-31. Boys' blouses, button-on waists, shirts and junior shirts.

15-29. Men's pajamas

16-29. Wall paper.

CS No. ITEM

18-29. Hickory golf shafts.

19-30. Foundry patterns of wood.

$20-30$. Staple vitreous china plumbing fixtures.

21-30. Interchangeable ground glass joints.

22-30. Builders' hard ware (nontemplate).

23-30. Feldspar.

24-30. Standard screw threads.

25-30. Special screw threads.

26-30. Aromatic red cedar closet lining.

27-30. Plate glass mirrors.

28-32. Cotton fabric tents, tarpaulins and covers.

29-31. Staple seats for water-closet bowls.

30-31. Colors for sanitary ware.

31-31. Red cedar shingles.

$32-31$. Cotton cloth for rubber and pyroxylin coating.

33-32. Knit underwear (exclusive of rayon).

34-31. Bag, case, and strap leather.

35-31. Plywood.

36-31. Fourdrinier wire cloth.

37-31. Steel bone plates and screws.

Noтісе.-Those interested in commercial standards with a view toward accepting them as a basis of everyday practice in their industry, may secure copies of the above standards, while the supply lasts, by addressing the Division of Trade Standards, Bureau of Standards, Washington, D. C. 
